\title{
Discovery of a novel gene involved in autolysis of Clostridium cells
}

\author{
Liejian Yang ${ }^{1,2}$, Guanhui Bao ${ }^{1,2}$, Yan Zhu ${ }^{1}$, Hongjun Dong ${ }^{1 凶}$, Yanping Zhang ${ }^{1}$, Yin Li $^{1 凶}$ \\ ${ }^{1}$ Key Laboratory of Microbial Physiological and Metabolic Engineering, Institute of Microbiology, Chinese Academy of Sciences, \\ Beijing 100101, China \\ ${ }^{2}$ University of the Chinese Academy of Sciences, Beijing 100049, China \\ $\triangle$ Correspondence: yli@im.ac.cn (Y. Li), redarmy305@gmail.com (H. Dong) \\ Received March 31, 2013 Accepted April 25, 2013
}

\begin{abstract}
Cell autolysis plays important physiological roles in the life cycle of clostridial cells. Understanding the genetic basis of the autolysis phenomenon of pathogenic Clostridium or solvent producing Clostridium cells might provide new insights into this important species. Genes that might be involved in autolysis of Clostridium acetobutylicum, a model clostridial species, were investigated in this study. Twelve putative autolysin genes were predicted in $C$. acetobutylicum DSM 1731 genome through bioinformatics analysis. Of these 12 genes, gene SMB_G3117 was selected for testing the intracellular autolysin activity, growth profile, viable cell numbers, and cellular morphology. We found that overexpression of SMB_G3117 gene led to earlier ceased growth, significantly increased number of dead cells, and clear electrolucent cavities, while disruption of SMB_G3117 gene exhibited remarkably reduced intracellular autolysin activity. These results indicate that SMB_G3117 is a novel gene involved in cellular autolysis of C. acetobutylicum.
\end{abstract}

KEYWORDS cell autolysis, autolysins, Clostridium, gene SMB_G3117

\section{INTRODUCTION}

Cell autolysis phenomenon is widespread among bacteria that possess peptidoglycan (Smith et al., 2000). Considering the possibility that cell autolysis is involved in selective removal of peptidoglycan, it might be involved in numerous cellular processes including cell growth, cell wall turnover, peptidoglycan maturation, cell division, cell lysis, motility, chemotaxis, genetic competence, differentiation, and pathogenicity (Foster, 1994;
Blackman et al., 1998). Clostridium is one of the largest bacterial genera, ranking the second in size next to Streptomyces, and classified as Gram-positive endospore-forming obligate anaerobes (Andreesen et al., 1989; Rehner and Samuels, 1994). Many species of Clostridium are pathogenic, e.g. C. botulinum, C. septicum, and C. difficile, while some species of Clostridium, e.g. C. acetobutylicum and C. beijerinckii, are also of biotechnological importance for solvents production. Understanding the genetic basis of autolysis of Clostridium cells is thus important for obtaining insights into the life cycle of this important species.

Acetone-butanol-ethanol (ABE) fermentation by solventproducing Clostridium represents one of the oldest industrial fermentation processes ever known, ranking second in scale only to ethanol fermentation by yeast (Lutke-Eversloh and Bahl, 2011). Recently, this process has been revived because of the potential application of butanol as an alternative biofuel (Lee et al., 2008). Typical batch fermentation process of $C$ acetobutylicum can be divided into two phases, acidogenesis and solventogenesis. Exponentially growing cells mainly produce acids in acidogenic phase, which were then reassimilated and converted to solvents by late-exponential growing cells in solventogenic phase. In the latter stage of solventogenesis, the optical density $\left(\mathrm{OD}_{600}\right)$ value usually sharply decreases, the so-called autolysis (Barber et al., 1979; Allcock et al., 1981). Autolysis of Clostridium cells might account for the diminished and even ceased production of solvents.

It is generally accepted that autolysis is triggered by autolysins, which are a group of bacteriolytic enzymes that digest the bacterial cell-wall peptidoglycan (Shockman and Holtje, 1994; Smith et al., 2000). In Gram-positive bacteria, autolysins can be classified into four main categories according to the specificity of their hydrolytic bonds, i.e. muramidases, glucosaminindases, $\mathrm{N}$-acetylmuramoyl-L-alanine amidases (amidas- 
es), and endopeptidases (Smith et al., 2000). In the last decades, autolysins in Escherichia coli (Holtje, 1995; Heidrich et al., 2001), Streptococcus (Ju et al., 2012; Tamura et al., 2012), Staphylococcus aureus (Jayaswal et al., 1990; Foster, 1995), lactic acid bacteria (ChapotChartier, 1996), and Bacillus subtilis (Blackman et al., 1998; Smith et al., 2000) have been extensively investigated. The autolysis phenomenon in ABE fermentation was firstly described in 1979 (Barber et al., 1979), but the molecular basis for autolysis of $C$. acetobutylicum remains poorly understood. Currently, only four lytic enzymes in solvent-producing clostridia have been partially purified and characterized. These include glycoprotein (28 kDa) (Webster et al., 1981), muramidase (41 kDa) (Croux et al., 1992b), and amidase (115 kDa) (Garcia et al., 1988) in C. acetobutylicum ATCC 824 , and $\mathrm{N}$-acetylmuramidase $(44 \mathrm{kDa})$ in $C$. saccharoperbutylacetonicum N I-4 (Yoshino et al., 1982). A gene CA C0554 in C. acetobutylicum ATCC 824, which encodes a lysozyme consisted of 324 amino acids with a calculated molecular mass of $34.939 \mathrm{kDa}$, was expressed in $E$. coli and characterized (Croux and Garcia, 1992).

The aim of this study was to identify and characterize genes that might be involved in cell autolysis of $C$. acetobutylicum DSM 1731. Autolysin relevant features including intracellular autolysin activity, growth profile, viable cell counts, and cellular morphology were performed. Finally, a novel gene, SMB_ G3117, was found to play a role in the autolysis of $C$. acetobutylicum cells.

\section{RESULTS}

Identification of putative autolysin genes in C. acetobutylicum through bioinformatics analysis

There are comprehensive descriptions concerning autolysins in Bacillus subtilis (Smith et al., 2000), which is moderately related to $C$. acetobutylicum (Nolling et al., 2001), thus providing a theoretical reference for our research. In $B$. subtilis 168 , eight genes representing conserved elements of four autolysin families (Table 1) were extracted from Kyoto Encyclopedia of Genes and Genomes (KEGG, http://www.genome.jp/kegg/). To identify genes encoding putative autolysin in C. acetobutylicum DSM 1731 (Bao et al., 2011), the sequences of 8 autolysin genes in $B$. subtilis 168 were individually used as query sequences to blast against $C$. acetobutylicum DSM 1731 genome with $E$-value $<10^{-5}$. Nine homologous genes were identified in the genome of $C$. acetobutylicum DSM 1731. To avoid missing target genes relevant to autolysin in DSM 1731, the sequences of these 9 genes were used to identify other possible autolysin genes through function domains search, resulting in 3 more candidate genes identified (Table 1), in which SMB G0566 and SMB_G1901 are paralog genes of SMB_G1126, while SMB_G3128 is paralog gene of SMB_G3117. In total, 12 putative autolysin genes were identified in the $C$. acetobutylicum DSM 1731 genome (Fig. 1). These genes can be divided into four categories on the basis of sequence similarities, i.e., muramidases (SMB_G0566, SMB_G1126, SMB_G1901), glucosaminindases (SMB_G2359), $\bar{N}$-acetylmuramoyl-L-alanine amidases (SMB_G0700, SMB_G3117, SMB_G3128), and endopeptidases (SMB_G0078, SMB_G0429, SMB_G0493, SMB_G2513, SMB_G3064).

\section{Preliminary evaluation of the putative autolysin genes in} C. acetobutylicum

All 12 putative autolysin genes were overexpressed in $C$. acetobutylicum SMB009 which is capable of accepting unmethylated DNA (Dong et al., 2010) to evaluate whether these genes are involved in autolysis. Considering that constitutive expression of autolysin genes may lead to cellular toxicity, the inducible expression vector pGusA2-2tetO1 that we previously developed (Dong et al., 2012) was used.

Twelve isolated transformants were cultivated in CGM medium supplemented with $50 \mu \mathrm{g} / \mathrm{mL}$ erythromycin (Em), and

Table 1. Identification of putative autolysin genes in $C$. acetobutylicum through bioinformatics analysis

\begin{tabular}{|c|c|c|c|c|}
\hline \multirow[t]{2}{*}{ Autolysin families } & \multirow{2}{*}{$\begin{array}{l}\text { B. subtilis } 168 \\
8 \text { query genes }\end{array}$} & \multicolumn{3}{|c|}{ C. acetobutylicum DSM 1731} \\
\hline & & 9 subject genes & Maximal similarity $^{a}$ & 3 paralog genes \\
\hline $\begin{array}{l}\text { Endopeptidases } \\
\text { (KO7052) }\end{array}$ & $\begin{array}{l}\text { BSU06010 } \\
\text { BSU23010 } \\
\text { BSU40830 }\end{array}$ & $\begin{array}{l}\text { SMB_G2513 } \\
\text { SMB_G0078 } \\
\text { SMB_G0493 } \\
\text { SMB_G0429 } \\
\text { SMB_G3064 }\end{array}$ & $\begin{array}{l}24.4 \% \\
24.2 \% \\
22.2 \% \\
23.6 \% \\
24.9 \%\end{array}$ & \\
\hline $\begin{array}{l}\text { Glucosaminindases } \\
\text { (KO1227) }\end{array}$ & BSU35780 & SMB_G2359 & $39.3 \%$ & \\
\hline $\begin{array}{l}\text { N-acetylmuramoyl-L-alanine } \\
\text { amidases (KO1449) }\end{array}$ & $\begin{array}{l}\text { BSU02600 } \\
\text { BSU13820 } \\
\text { BSU22930 }\end{array}$ & $\begin{array}{l}\text { SMB_G0700 } \\
\text { SMB_G3117 }\end{array}$ & $\begin{array}{l}34.2 \% \\
22.6 \%\end{array}$ & SMB_G3128 \\
\hline Muramidases & BSU14071 & SMB_G1126 & $23.7 \%$ & $\begin{array}{l}\text { SMB_G0566 } \\
\text { SMB_G1901 }\end{array}$ \\
\hline
\end{tabular}

${ }^{\text {a }}$ Similarity of amino acid sequence. 


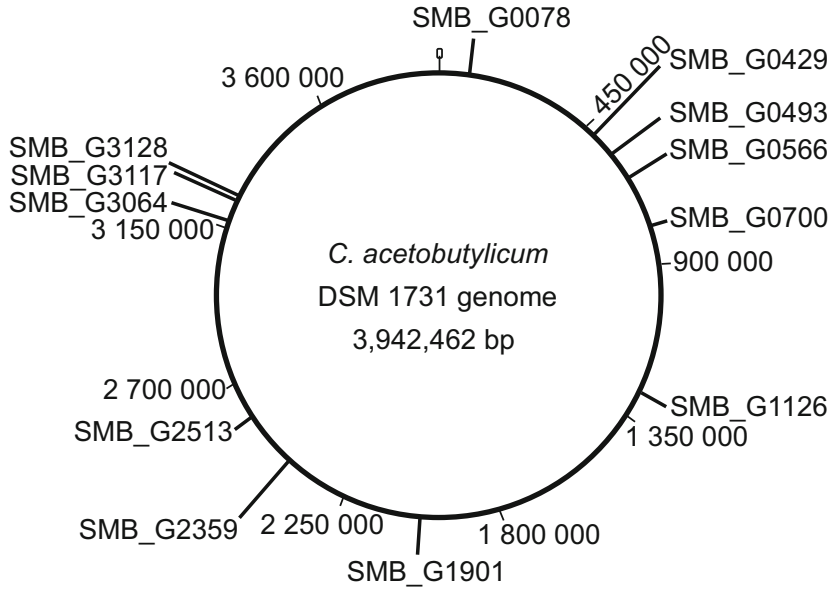

Figure 1. The distribution of 12 putative autolysin genes in $C$. acetobutylicum DSM 1731 genome.

$100 \mathrm{ng} / \mathrm{mL}$ anhydrotetracycline (aTc) for inducible expression. The results (Fig. 2A) showed that only inducible expression of gene SMB_G2359 (Fig. 2A-a) and SMB_G3117 (Fig. 2A-b) led to a $53.4 \%$ and $72.3 \%$ decrease of $\mathrm{OD}_{600}$, respectively, as compared to that of the control. We also observed that inducible expression of SMB_G2359 and SMB_G3117 at OD 600 $=0.5$ (around $6 \mathrm{~h}$ ) (Fig. 2B) led to a 13\% and 10\% decrease of $\mathrm{OD}_{600}$, while the non-induced strain (Fig. $2 \mathrm{C}$ ) showed the same $\mathrm{OD}_{600}$, as compared to the control. This suggests that gene SMB_G2359 and SMB_G3117 might play a role in cell lysis.

To investigate the specific function of the selected gene SMB_G2359 and SMB_G3117, attempts to disrupt these genes in C. acetobutylicum DSM1731 were made using ClosTron pMTL008 vector (Dong et al., 2010; Heap et al., 2010). To disrupt gene SMB_G2359, three targeted intron insertion sites (732/733s, 867/868s, and 1292/1293s) were tested, respectively. For each target site, more than 200 integrants were screened through colony PCR (Table S1). Unexpectedly, no positive integrants were obtained, suggesting that gene SMB G2359 might be essential for cell growth. Gene SMB_G3117 was successfully disrupted, generating mutant strain KO3117. Therefore, gene SMB_G3117 was selected for further investigation.

\section{Functional analysis of gene SMB_G3117 in}

\section{C. acetobutylicum DSM 1731}

To further investigate the function of gene SMB_G3117, we compared the autolysis related features of the SMB_G3117 disrupted strain KO3117, the SMB_G3117 inducibly expressed strain DSM 1731 (p3117), with their control strains wild type strain DSM 1731 and strain DSM 1731 (p2tetO1), respectively. The tested features include intracellular autolysin activity characterized as the decrease of $\mathrm{OD}_{600}$ in sodium phosphate buffer, growth profile (increase of $\mathrm{OD}_{600}$ ), viable cell counts (spreading plates and colony counting), and cellular morphology (TEM observation).

Compared to wild type strain DSM 1731, the intracellular autolysin activity of the mutant strain KO3117 decreased by $37.7 \%$ (Fig. 3C). Nevertheless, no significant difference was observed in growth profile, viable cell numbers (Fig. 3A and 3B), and cellular morphology (Fig. 4C and 4D) between these two strains. We examined the dynamic transcriptional profile of $C$. acetobutylicum ATCC 824 published in a previous study (Jones et al., 2008) and calculated the expression level of relevant genes. The expression level of the gene CA_C3081 in strain ATCC 824 (same to SMB_G3117 in strain DSM 1731; the genome of strain ATCC 824 and DSM 1731 are highly similar (Bao et al., 2011)) was 5-fold lower than the average transcription level of all genes during vegetative growth (Fig. 5). This suggests that the expression level of SMB_G3117 might be quite low, so that the disruption of this gene in wild type did not exhibit clear phenotype.

Clear autolysis related phenotypes were observed in strain DSM 1731 (p3117). Growth profile assay also revealed that the cease of growth of strain DSM 1731 (p3117) occurred at $12 \mathrm{~h}$, which was $12 \mathrm{~h}$ ahead of the control strain (Fig. 3D). In addition, the viable cell numbers of strain DSM 1731 (p3117) were 15-fold less than its control strain (Fig. 3E). Moreover, TEM analysis (Fig. 4A and 4B) showed that electrolucent cavities, which were termed as "nuclear vacuoles" previously (Eltsov and Zuber, 2006), were clearly observed in strain DSM 1731 (p3117) at $12 \mathrm{~h}$, in sharp contrast with that of the control strain. We also observed that the intracellular autolysin activity of strain DSM 1731 (p3117) was increased by $14.0 \%$ (Fig. 3F), not as high as expected though. All these observations conceive that SMB_G3117 overexpression led to significant cellular autolysis during vegetative growth.

\section{DISCUSSION}

In this study, two genes SMB_G2359 and SMB_G3117 that might contribute to autolysis of $C$. acetobutylicum were identified from twelve putative autolysin genes under the available experimental conditions. Gene SMB_G2359, annotated as Nacetylglucosaminidase domain- and $\mathrm{ChW}$ repeat-containing cell wall hydrolase (encoded by lytD gene), is the only predicted autolysin gene in LytD glucosaminidase family. In B. subtilis, only one lytD gene was identified and proved to be one of the major autolysins. However, the lyt $D$ mutant of $B$. subtilis still exhibits glucosaminidase activity, suggesting alternative glucosaminidase genes may exist in the genome (Rashid et al., 1993). The failure to disrupt SMB_G2359 in this work may indicate that this gene is the only one responsible for glucosaminidase activity in $C$. acetobutylicum.

Inducible expression of gene SMB_G3117 led to severely weakened cell viability and integrity, and caused cell autolysis. However, disruption of this gene in C. acetobutylicum DSM1731 did not exhibit growth difference compared to wild type strain. This suggests that the expression of gene SMB_ 
A

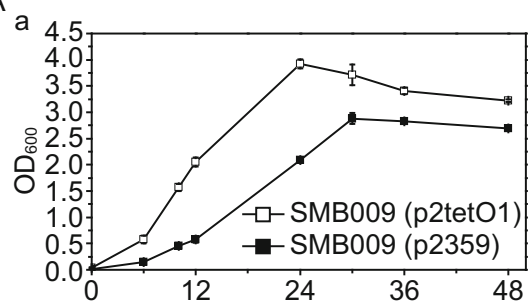

d 4.5
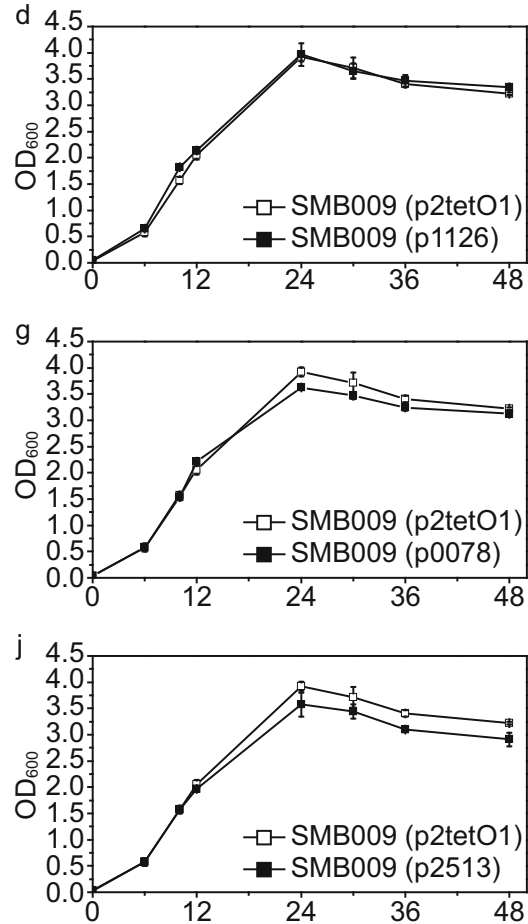

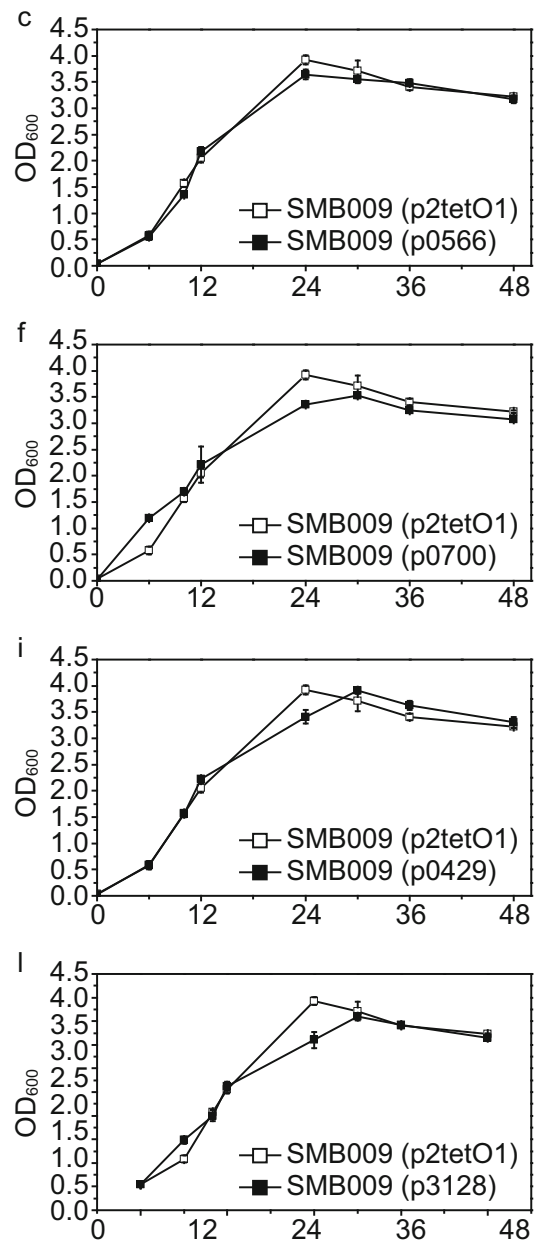

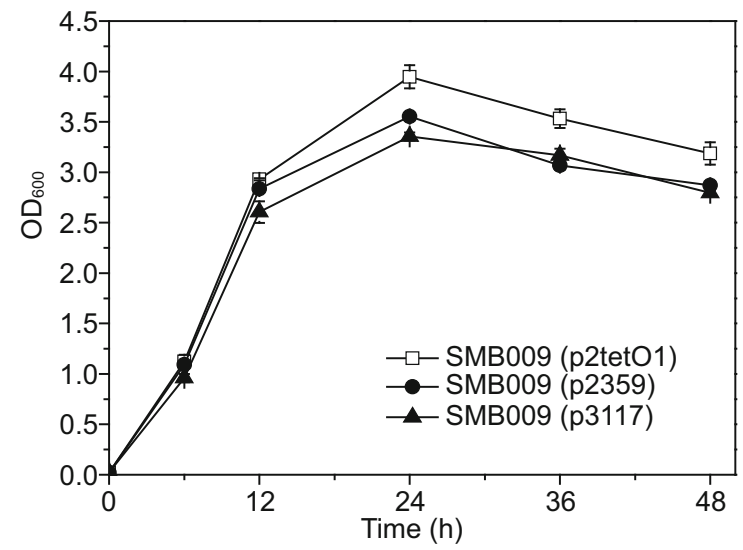

C

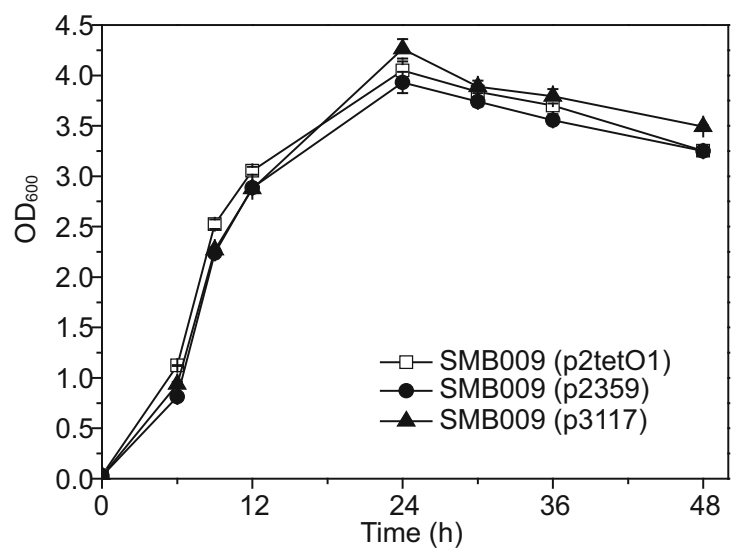

Figure 2. Growth profiles of aTc-inducible expression of predicted autolysin relevant genes in CGM medium. (A) Twelve predicted autolysin relevant genes with addition of aTc at $0 \mathrm{~h}$. (B) Two critical autolysin relevant genes with addition of aTc at $O D_{600}=0.5$. (C) Two critical autolysin relevant genes without addition of aTc. Values are mean of triplicates and error bars represent standard deviations $(n=3)$. 
A

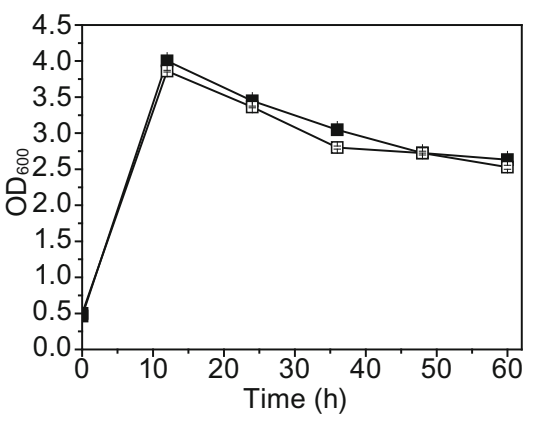

$\mathrm{D}$



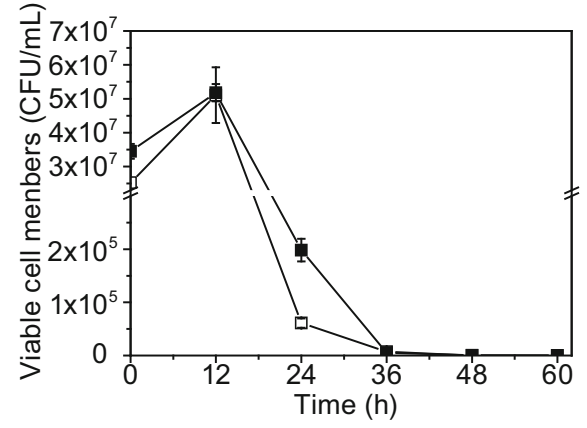

Eว

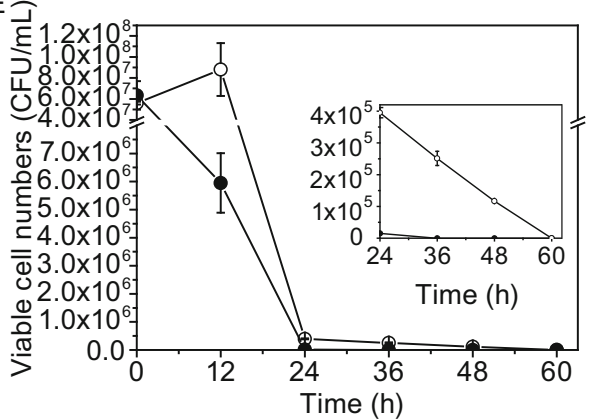

C



$\mathrm{F}$

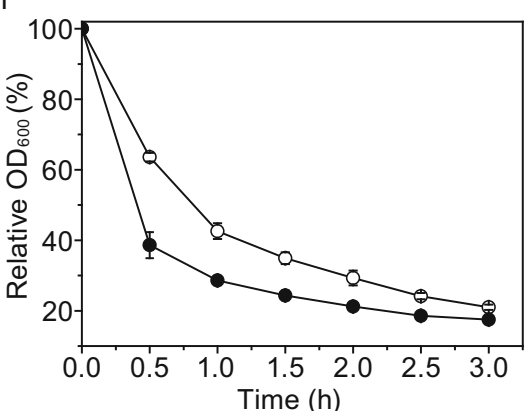

Figure 3. Functional analysis of gene SMB_G3117 in C. acetobutylicum DSM 1731. Effect of disruption of gene SMB G3117 on growth (A), viable cell numbers (B), and intracellular autolysin activities (C); Effect of inducible expression of gene SMB_G3117 on growth (D),


(p2tetO1). Values are mean of triplicates and error bars represent standard deviations $(n=3)$.

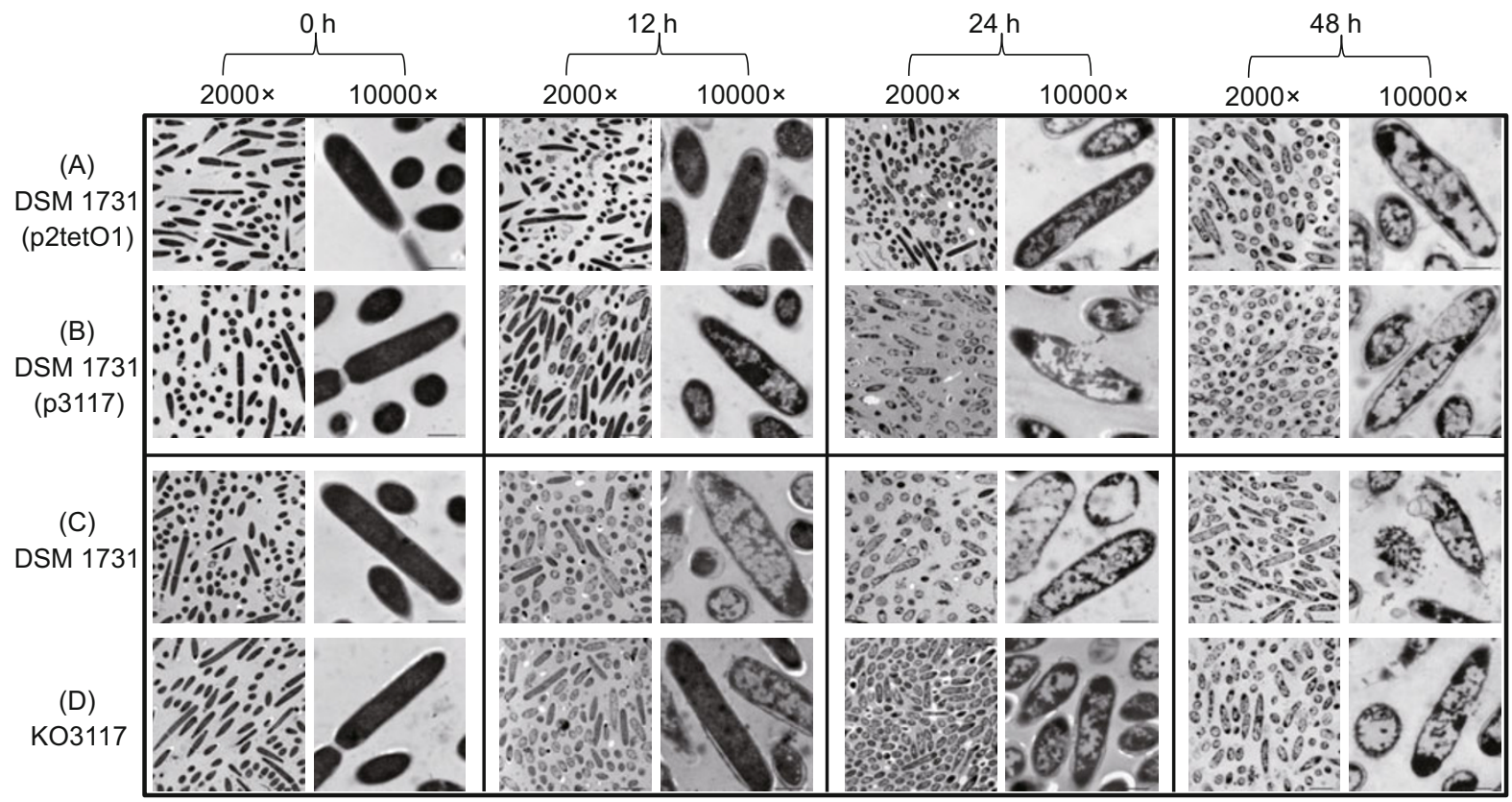

Figure 4. Effect of disruption or overexpression of gene SMB_G3117 on cellular morphology. The dark particles (0-12 h) are ribosomes and the ribosome-free spaces contain chromatin (Levin-Zaidman et al., 2000). Electrolucent cavities (Eltsov and Zuber, 2006), the so-called "nuclear vacuoles", were present at the post-exponential phase of growth (12-24 h). Typical endospore was formed with a developing endospore and electron translucent granulose was still visible at the end phase of growth (24-48 h). Scale bars for $2000 \times$ panels, $2.0 \mu \mathrm{m}$; scale bars for $10,000 \times$ panels, $500.0 \mathrm{~nm}$. 


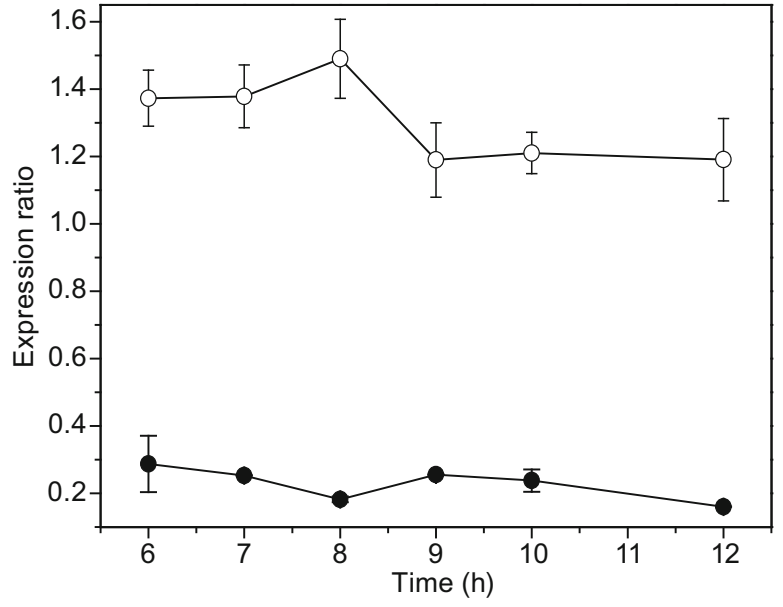

Figure 5. Transcriptional profiles for CA_C3081 in C. acetobutylicum ATCC 824 (same to SMB_G3117 of C. acetobutylicum DSM 1731) based on time-series microarray analysis of a published paper (Jones et al., 2008). Data from this paper was used to interrogate the transcript abundance of CA_C3081, with the average abundance of all transcripts calculated as a reference. Symbols: • the expression ratios of CA_C3081; o, the average of expression ratios of all genes.
G3117 is tightly regulated to avoid overexpression to a lethal level. Although gene SMB_G3117 is annotated as sporecortex-lytic enzyme, a type of $\mathrm{N}$-acetylmuramoyl-L-alanine amidases, our results showed that overexpression of gene SMB G3117 triggered autolysis of C. acetobutylicum during vegetative growth. In another recent study, a novel Streptococcus suis gene at/ containing one $\mathrm{N}$-acetyl-muramoyl-L-alanine amidase domain, also exhibited autolysis activity in conditions consistent with our study, and was proved to take part in cell autolysis and separation of daughter cells (Ju et al., 2012). This suggests that the autolysis function of SMB_G3117, as revealed in this study, might be an important part of the life cycle of $C$. acetobutylicum cells that is worthy of further investigation.

\section{MATERIALS AND METHODS}

Strains, plasmids and culture conditions

The bacterial strains and plasmids used in the present study are listed in Table 2. Escherichia coli strains were routinely grown aerobically at $37^{\circ} \mathrm{C}$ and $200 \mathrm{r} / \mathrm{min}$ in liquid LB medium or solid LB with agar (1.5\%) medium supplemented, when necessary, with ampicillin $(100 \mathrm{mg} / \mathrm{mL})$ and/or chloramphenicol $(\mathrm{Cm}, 30 \mathrm{mg} / \mathrm{mL})$. All $C$. acetobutylicum strains were grown anaerobically at $37^{\circ} \mathrm{C}$ in liquid RCM medium (Hirsch and Grinsted, 1954) or solid RCM with agar (1.5\%) medium supplemented,

Table 2. Strains and plasmids used in this study

\begin{tabular}{|c|c|c|}
\hline Strain or plasmid & Relevant characteristics $^{\mathrm{a}}$ & Source or reference ${ }^{b}$ \\
\hline \multicolumn{3}{|l|}{ Strains } \\
\hline \multicolumn{3}{|l|}{ C. acetobutylicum } \\
\hline DSM 1731 & Wild type & DSMZ \\
\hline SMB009 & CAC1502::intron & Dong et al., 2010 \\
\hline DSM 1731 (p2tetO1) & $\begin{array}{l}\text { Plasmid control strain of DSM } 1731 \text {, } \\
\text { containing control vector p2tetO1 }\end{array}$ & This study \\
\hline DSM 1731 (p3117) & $\begin{array}{l}\text { Inducible expression strain of DSM 1731, containing gene SMB_G3117 } \\
\text { expression vector p3117 }\end{array}$ & This study \\
\hline KO3117 & SMB_G3117::intron & This study \\
\hline \multicolumn{3}{|l|}{ E. coli } \\
\hline $\mathrm{DH} 5 \mathrm{a}$ & General cloning host strain & TaKaRa \\
\hline ER2275 & hsdR mor recA1 endA1 & NEB \\
\hline TOP10 & $m c r A \Delta(m r r-h s d R M S-m c r B C)$ recA1 & Invitrogen \\
\hline \multicolumn{3}{|l|}{ Plasmids } \\
\hline pAN1 & $\Phi 3 t$ gene, $p 15 a$ ori, $\mathrm{Cm}^{r}$ & Mermelstein et al., 1992 \\
\hline pGusA2-2tetO1 & $\mathrm{Amp}^{r}, \mathrm{MLS}^{r}$, aTc-inducible gene expression vector containing gusA gene & Dong et al., 2012 \\
\hline p2tetO1 & Control vector by removing the gus $A$ gene and self-ligation & This study \\
\hline p3117 & pGusA2-2tetO1 containing SMB_G3117 gene (replacing gusA) & This study \\
\hline pAN2 & $\Phi 3 t$ I gene, p15a ori, Tet ${ }^{r}$ & Heap et al., 2007 \\
\hline pMTL008 & ClosTron vector & Dong et al., 2010 \\
\hline pMTL008-3117 & For SMB_G3117 gene disruption by group II intron method & This study \\
\hline
\end{tabular}


when necessary, with chloramphenicol $(\mathrm{Cm}, 30 \mathrm{mg} / \mathrm{mL})$, erythromycin $(\mathrm{Em}, 50 \mathrm{mg} / \mathrm{mL})$ and anhydrotetracycline (aTc, $100 \mathrm{ng} / \mathrm{mL})$. The CGM medium (Hartmanis and Gatenbeck, 1984) was also used for $C$. acetobutylicum growth. All C. acetobutylicum and E. coli strains were maintained frozen in $15 \%(\mathrm{~V} / \mathrm{V})$ glycerol at $-80^{\circ} \mathrm{C}$.

\section{Construction of gene SMB_G3117 inducible expression strains}

The primers used to amplify these 12 genes are listed in Table S1. Twelve inducible expression vectors were constructed by replacing gusA gene with corresponding putative autolysin genes in pGusA22tetO1 using restriction enzyme Spel (or $\mathrm{Ncol}$ ) and Xhol. The control plasmid p2tetO1 was generated by removing gusA gene in pGusA22tetO1 using the same restriction enzyme digestion, end-filling using high fidelity DNA polymerase, and then self-ligation. Inducibleautolysin-expression strains were obtained by electrotransforming the respective 12 plasmids into $C$. acetobutylicum SMB009 according to the protocol developed previously (Mermelstein et al., 1992).

\section{Construction of gene SMB_G3117 disrupted mutant}

Retargeted gene ClosTron plasmids were constructed as previously described using plasmid pMTL008 (Dong et al., 2010). The primers used for the construction of these plasmids are listed in Table S1. The resulted plasmid, designated as PMTL008-3117, was confirmed by DNA sequencing using primer 14-007-R1. pMTL008-3117, methylated by co-transforming pAN2 into E. coli TOP10, was then electrotransformed into the strain DSM1731, resulting in strain KO3117. Integrants were selected on the basis of acquisition of chloramphenicol resistance, and then reselected again through erythromycin resistance. The positive integrant was screened through a number of diagnostic PCR and further confirmed by three pairs of primers (Fig. S1). Finally, the fragments generated were subject to nucleotide sequence analysis to definitively confirm that insertion had occurred at the desired position.

\section{Growth measurement}

Cell optical densities at $600 \mathrm{~nm}$ were measured dynamically using a UV-visible spectrophotometer (UV-2802PC, Unico, Shanghai, China). Samples were diluted in the appropriate medium to ensure an absorbance below 0.50 .

\section{Viable cell counts assay}

A CFU (colony-forming unit) assay is employed to count the viable cell numbers (Zingaro and Terry Papoutsakis, 2012). The unit of measurement is CFU/mL. Strains were cultivated in CGM medium supplemented with $50 \mu \mathrm{g} / \mathrm{mL}$ erythromycin (Em), and $100 \mathrm{ng} / \mathrm{mL}$ aTc for inducible expression. Samples from different growth phases were serially diluted in sterile liquid media. Dilution level was determined based on $A_{600}$ measurements of the samples. One hundred microliter diluted broth was taken from dilution series and spread onto agar solidified CGM plate containing appropriate antibiotics. Viable cell numbers were calculated after incubating anaerobically at $37^{\circ} \mathrm{C}$ for $24 \mathrm{~h}$.

Intracellular autolysin activity of the inducible expression and disruption of gene SMB_G3117

Intracellular autolysin activity assay of the inducible-expression and disruption of gene SMB_G3117 was performed according to modified procedures (Croux et al., 1992a). Exponential phase cells $\left(\mathrm{OD}_{600}=2.0\right)$ were harvested by centrifugation $\left(12,000 \mathrm{~g}, 5 \mathrm{~min}, 4^{\circ} \mathrm{C}\right)$ and after the supernatant fluid had been discarded, residual growth medium was removed with cotton tips. The pellet was washed once with $0.1 \mathrm{~mol} / \mathrm{L}$ sodium phosphate buffer $(\mathrm{pH}$ 6.3). The washed pellet was then diluted to an initial $\mathrm{OD}_{600}$ of 1 into preincubated $\left(37^{\circ} \mathrm{C}\right) 0.1 \mathrm{~mol} / \mathrm{L}$ sodium phosphate buffer ( $\mathrm{pH}$ 6.3). Note that $100 \mathrm{ng} / \mathrm{mL}$ aTc was added in the inducibleexpression group. The decreases in $\mathrm{OD}_{600}$ were monitored at $37^{\circ} \mathrm{C}$ every $0.5 \mathrm{~h}$.

Cellular morphology of the inducible expression and disruption of gene SMB_G3117 through TEM observation

All strains were cultivated as mentioned in growth and viable cell counts assay. Cells were collected by centrifugation $(12,000 \mathrm{~g}, 5 \mathrm{~min}$, $\left.4^{\circ} \mathrm{C}\right)$ at different phase of growth $(0 \mathrm{~h}, 12 \mathrm{~h}, 24 \mathrm{~h}, 48 \mathrm{~h})$ then fixed instantly by adding $2.5 \%(\mathrm{v} / \mathrm{V})$ glutaraldehyde for more than $2 \mathrm{~h}$, respectively. Samples for TEM were prepared as described previously (Jones et al., 2008; Zhang et al., 2010). Prepared cell thin sections were examined with a transmission electron microscope (JEM-1400; JEOL Ltd., Japan) operating at an acceleration voltage of $80 \mathrm{kV}$.

\section{ACKNOWLEDGEMENTS}

This research was supported by grants from the National Natural Science Foundation of China (Grant No. 31270107) and the National High Technology Research and Development Program (863 Program) (No. 2011AA02A208). Yanping Zhang is supported by grants from the Knowledge Innovation Program of the Chinese Academy of Sciences (No. KSCX2-EW-Q-14). We thank Jingnan Liang for her assistance in TEM observation.

\section{COMPLIANCE WITH ETHICS GUIDELINES}

Liejian Yang, Guanhui Bao, Yan Zhu, Hongjun Dong, Yanping Zhang and Yin Li declare that they have no conflict of interest.

This article does not contain any studies with human or animal subjects performed by the any of the authors.

\section{REFERENCES}

Allcock, E.R., Reid, S.J., Jones, D.T., and Woods, D.R. (1981). Autolytic activity and an autolysis-deficient mutant of Clostridium acetobutylicum. Appl Environ Microbiol 42, 929-935.

Andreesen, J., Bahl, H., and Gottschalk, G. (1989). Introduction to the physiology and biochemistry of the genus Clostridium. Clostridia. 27-62. Edited by Minton, N. and Clarke, D. New York and London: Plenum Press.

Bao, G., Wang, R., Zhu, Y., Dong, H., Mao, S., Zhang, Y., Chen, Z., Li, Y., and Ma, Y. (2011). Complete genome sequence of Clostridium acetobutylicum DSM 1731, a solvent-producing strain with multireplicon genome architecture. J Bacteriol 193, 5007-5008.

Barber, J.M., Robb, F.T., Webster, J.R., and Woods, D.R. (1979). Bacteriocin production by Clostridium acetobutylicum in an industrial fermentation process. Appl Environ Microbiol 37, 433-437.

Blackman, S.A., Smith, T.J., and Foster, S.J. (1998). The role of autolysins during vegetative growth of Bacillus subtilis 168 . Microbiol-UK 144, 73-82. 
ChapotChartier, M.P. (1996). Autolysins of lactic acid bacteria. Lait 76, 91-109.

Croux, C., Canard, B., Goma, G., and Soucaille, P. (1992a). Autolysis of Clostrtdium acetobutylicum ATCC 824. J Gen Microbiol 138, 861-869.

Croux, C., Canard, B., Goma, G., and Soucaille, P. (1992b). Purification and characterization of an extracellular muramidase of Clostridium acetobutylicum ATCC 824 that acts on non-N-acetylated peptidoglycan. Appl Environ Microbiol 58, 1075-1081.

Croux, C., and Garcia, J.L. (1992). Reconstruction and expression of the autolytic gene from Clostridium acetobutylicum ATCC 824 in Escherichia coli. FEMS Microbiol Lett 74, 13-20.

Dong, H., Tao, W., Zhang, Y., and Li, Y. (2012). Development of an anhydrotetracycline-inducible gene expression system for solventproducing Clostridium acetobutylicum: A useful tool for strain engineering. Metab Eng 14, 59-67.

Dong, H., Zhang, Y., Dai, Z., and Li, Y. (2010). Engineering Clostridium strain to accept unmethylated DNA. PLoS ONE 5, e9038.

Eltsov, M., and Zuber, B. (2006). Transmission electron microscopy of the bacterial nucleoid. J Struct Biol 156, 246-254.

Foster, S.J. (1994). The role and regulation of cell-wall structural dynamics during differentiation of endospore-forming bacteria. J Appl Bacteriol 76, S25-39.

Foster, S.J. (1995). Molecular characterization and functional analysis of the major autolysin of Staphylococcus aureus 8325/4. J Bacteriol 177, 5723-5725.

Garcia, J.L., Garcia, E., Sanchezpuelles, J.M., and Lopez, R. (1988). Identification of a Iytic enzyme of Clostridium acetobutylicum that degrades choline-containing pneumococcal cell walls. Fems MicrobiolLett 52, 133-137.

Hartmanis, M.G., and Gatenbeck, S. (1984). Intermediary metabolism in Clostridium acetobutylicum: levels of enzymes involved in the formation of acetate and butyrate. Appl Environ Microbiol 47, 12771283.

Heap, J.T., Kuehne, S.A., Ehsaan, M., Cartman, S.T., Cooksley, C.M., Scott, J.C., and Minton, N.P. (2010). The ClosTron: mutagenesis in Clostridium refined and streamlined. J Microbiol Methods 80, 49-55.

Heidrich, C., Templin, M.F., Ursinus, A., Merdanovic, M., Berger, J., Schwarz, H., de Pedro, M.A., and Holtje, J.V. (2001). Involvement of $\mathrm{N}$-acetylmuramyl-L-alanine amidases in cell separation and antibiotic-induced autolysis of Escherichia coli. Mol Microbiol 41, 167-178.

Hirsch, A., and Grinsted, E. (1954). Methods for the growth and enumeration of anaerobic spore-formers from cheese, with observations on the effect of nisin. J. Dairy Res. 21, 101-110.

Holtje, J.V. (1995). From growth to autolysis: the murein hydrolases in Escherichia coli. Arch Microbiol 164, 243-254.

Jayaswal, R.K., Lee, Y.I., and Wilkinson, B.J. (1990). Cloning and expression of a Staphylococcus aureus gene encoding a peptidoglycan hydrolase activity. J Bacteriol 172, 5783-5788.

Jones, S.W., Paredes, C.J., Tracy, B., Cheng, N., Sillers, R., Senger,
R.S., and Papoutsakis, E.T. (2008). The transcriptional program underlying the physiology of clostridial sporulation. Genome Biol 9 R114.

Ju, C.X., Gu, H.W., and Lu, C.P. (2012). Characterization and functional analysis of atl, a novel gene encoding autolysin in Streptococcus suis. J Bacteriol 194, 1464-1473.

Kuehne, S.A., Heap, J.T., Cooksley, C.M., Cartman, S.T., and Minton, N.P. (2011). ClosTron-mediated engineering of Clostridium. In Strain Engineering (Springer), pp. 389-407.

Lee, S.Y., Park, J.H., Jang, S.H., Nielsen, L.K., Kim, J., and Jung, K.S. (2008). Fermentative butanol production by Clostridia. Biotechnol Bioeng 101, 209-228.

Lutke-Eversloh, T., and Bahl, H. (2011). Metabolic engineering of Clostridium acetobutylicum: recent advances to improve butanol production. Curr Opin Biotechnol 22, 634-647.

Mermelstein, L.D., Welker, N.E., Bennett, G.N., and Papoutsakis, E.T. (1992). Expression of cloned homologous fermentative genes in Clostridium acetobutylicum ATCC 824. Nat Biotech 10, 190-195.

Nolling, J., Breton, G., Omelchenko, M.V., Makarova, K.S., Zeng, Q.D., Gibson, R., Lee, H.M., Dubois, J., Qiu, D.Y., Hitti, J., et al. (2001). Genome sequence and comparative analysis of the solventproducing bacterium Clostridium acetobutylicum. J Bacteriol 183, 4823-4838.

Rashid, M.H., Kuroda, A., and Sekiguchi, J. (1993). Bacillus subtilis mutant deficient in the major autolytic amidase and glucosaminidase is impaired in motility. FEMS Microbiol Lett 112, 135-140.

Rehner, S.A., and Samuels, G.J. (1994). Taxonomy and phylogeny of gliocladium analyzed from nuclear large subunit ribosomal DNAsequences. Mycol Res 98, 625-634.

Shockman, G.D., and Holtje, J.-V. (1994). Microbial peptidoglycan (murein) hydrolases. In Bacterial Cell Wall, J.-M. Ghuysen, and R. Hakenbeck, eds. (Amsterdam, Elsevier), pp. 131-166.

Smith, T.J., Blackman, S.A., and Foster, S.J. (2000). Autolysins of Bacillus subtilis: multiple enzymes with multiple functions. MicrobiolUK 146, 249-262.

Tamura, H., Yamada, A., and Kato, H. (2012). Identification and characterization of an autolysin gene, atlA, from Streptococcus criceti. J Microbiol 50, 777-784.

Webster, J.R., Reid, S.J., Jones, D.T., and Woods, D.R. (1981). Purification and characterization of an autolysin from Clostridium acetobutylicum. Appl Environ Microbiol 41, 371-374.

Yoshino, S., Ogata, S., and Hayashida, S. (1982). Some properties of autolysin of Clostridium saccharoperbutylacetonicum. Agric Biol Chem 46, 1243-1248.

Zhang, Y.H., Zhang, Y.P., Zhu, Y., Mao, S.M., and Li, Y. (2010). Proteomic analyses to reveal the protective role of glutathione inresistance of Lactococcus lactis to osmotic stress. Appl Environ Microbiol 76, 3177-3186.

Zingaro, K.A., and Terry Papoutsakis, E. (2013). GroESL overexpression imparts Escherichia coli tolerance to i-, n-, and 2-butanol, 1,2,4-butanetriol and ethanol with complex and unpredictable patterns. Metab Eng 15, 196-205. 